\title{
IMPLEMENTASI MODEL PEMBELAJARAN TEACHING INDUSTRY BERBASIS KEWIRAUSAHAAN DAN MOTIVASI BELAJAR TERHADAP PENINGKATAN KOMPETENSI KEAHLIAN PRODUKTIF BUSANA BUTIK DAN PATISERI
}

\author{
Cucu Sutianah \\ SMK Negeri 9 Bandung, Jl. Soekarno-Hatta Km. 10 Bandung 40286 \\ yustiana_nengucu@yahoo.com
}

\begin{abstract}
Abstrak : Penelitian ini bertujuan mengetahui seberapa besar kontribusi implementasi model teaching industry berbasis kewirausahaan dan motivasi belajar siswa terhadap peningkatan kompetensi keahlian produktif Busana Butik dan Patiseri di SMK Negeri 9 Bandung. Metode yang ditempuh untuk menjawab permasalahan adalah melalui pendekatan kuantitatif dengan teknik korelasional. Pengumpulan data dilaksanakan melalui penyebaran angket dan studi dokumentasi. Sampel dalam penelitian ini menggunakan sampel populasi . Uji korelasi dan uji t hasil penelitian sebagai berikut: besarnya kontribusi implementasi pembelajaran model teaching industry kewirausahaan berbasis terhadap peningkatan kompetensi keahlian produktif mempunyai kriteria cukup tinggi), besarnya kontribusi motivasi belajar terhadap peningkatan kompetensi keahlian produktif Busana Butik dan Patiseri.mempunyai kriteria tinggi dan besarnya kontribusi implementasi pembelajaran model teaching industry kewirausahaan berbasis kewirausahaan dan motivasi belajar terhadap peningkatan kompetensi keahlian produktif mempunyai kriteria tinggi.
\end{abstract}

Kata Kunci: Pembelajaran model teaching industry, motivasi belajar, keahlian produktif.

\begin{abstract}
This study aims to examine the formulated problems; to know to what extent the implementation contribution of entrepreneurship-based teaching industry model, and students' learning motivation towards boutique and patisserie productive skill competence increase in SMK N 9 Bandung. The method adopted to address problems is quantitative approach with correlation techniques. Data collection is conducted through questionnaire dissemination and document studies. This study uses population sample. Results of correlation test and t test are as follow: implementation contribution magnitude of entrepreneurship-based teaching industry model on productive skill competence increase is in fairly high criteria, contribution magnitude of learning motivation on increase in boutique and patisserie productive skills competence has high criteria and implementation contribution magnitude of entrepreneurship-based teaching industry model and learning motivation towards productive skills competence increase has high criteria.
\end{abstract}

Keywords: entrepreneurship-based teaching industry model learning, learning motivation, productive skill competency increase

\section{PENDAHULUAN}

Permasalahan yang paling mendasar pada penyelenggaraan Sekolah Menengah Kejuruan di Indonesia adalah dalam rangka menghilangkan kesenjangan atau gap antara lembaga sekolah dengan kebutuhan, minat dan bakat peserta didiknya. Seperti yang dikemukakan oleh Hamalik (1990: 88) bahwa: 
"Persoalan pokok sehubungan dengan pendidikan kejuruan adalah, bagaimana menyelenggarakan pendidikan kejuruan yang sesuai dengan kebutuhan, minat dan bakat generasi muda untuk mempersiapkan mereka memasuki dunia kerja, serta mampu menyesuaikan diri dengan perubahan dan kemajuan teknologi yang cepat dewasa ini”.

Penyelenggaraan SMK itu harus tepat guna (effective) artinya, seperti yang dikemukakan oleh Barlow ( 1974: 276) bahwa: “...Vocational education will be effective in proportion to the kinds and quality of community interaction... Vocational education must be seen as a partnership between the school and the community."

Penyelenggaraan SMK harus diarahkan pada mempersiapkan individu dengan pemahaman pekerjaan dari dunia kerja dan keterampilan mengerjakan pekerjaan dan juga pengetahuan praktis. Dewasa ini, dalam rangka mempersiapkan lulusan yang dapat memenuhi tuntutan profesional dunia kerja atau industri. Sekolah Menengah Kejuruan (SMK) memiliki peran yang sangat penting sebagai pemenuhan kebutuhan (demand driver) tenaga kerja profesional tingkat menengah, seperti yang dinyatakan Litbang Diknas dalam naskah akademik (RPP: 2001) Pendidikan menengah bahwa sekolah menengah kejuruan adalah pendidikan pada jenjang pendidikan menengah yang mengutamakan pengembangan kemampuan siswa untuk melaksanakan jenis pekerjaan tertentu.

Rendahnya kualitas lulusan sekolah kejuruan berakibat produktifitas tenaga kerja terampil di dunia industri semakin terpuruk. Kepercayaan dunia industri semakin berkurang sehingga lulusan yang terserap juga sedikit. Salah satu faktor penyebab adalah kurikulum yang terus berubah menyebabkan kondisi di lembaga pengelola pendidikan kejuruan semakin terbebani.

Kualitas lulusan SMK yang disarikan dari Finch dan Crunkilton (1979), bahwa : "Kualitas pendidikan kejuruan menerapkan ukuran ganda, yaitu kualitas menurut ukuran sekolah atau in-school success standards dan kualitas menurut ukuran masyarakat atau out-of school success standards". Kriteria pertama meliputi aspek keberhasilan peserta didik dalam memenuhi tuntutan kurikuler yang telah diorientasikan pada tuntutan dunia kerja, sedangkan kriteria kedua, meliputi keberhasilan peserta didik yang tertampilkan pada kemampuan unjuk kerja sesuai dengan Standar Kompetensi Naisonal (SKN), setelah mereka berada di lapangan kerja yang sebenarnya. 
Pendidikan yang paling sesuai untuk meningkatkan hal tersebut adalah pendidikan yang berorentasi pada dunia industri dengan penekanan pada pendekatan pembelajaran dan didukung oleh kurikulum yang sesuai. Dunia industri yang merupakan sasaran dari proses dan hasil pembelajaran sekolah menengah kejuruan mempunyai karakter dan nuansa tersendiri. Oleh karena itu lembaga pendidikan kejuruan dalam proses pembelajaran harus bisa membuat pendekatan pembelajaraan yang tepat dan sesuai dengan keinginan dunia industri.

Upaya mempersiapkan ahli-ahli tingkat menengah yang kompeten, siap bekerja dan mandiri sesuai dengan harapan dunia industri, kegiatan pembelajaran di SMK sudah seharusnya mendayagunakan potensi yang dimiliki sekolah baik ruang praktikum dengan sarana prasarana yang terstandar dengan mengintegrasikan model-model pembelajaran yang bervariasi. Materi pembelajaran harus selalu mengikuti kebutuhan masyarakat nyata dengan mendayagunakan ruang Laboratorium praktik secara tepat, efektif dan produktif.

Siswa agar lebih termotivasi dalam kegiatan pembelajaran perlu mendapat peerhatian yang cukup, terutama dengan memperhatikan (1) kebutuhan belajarnya, (2) kebutuhan fisiologis, (3) kebutuhan rasa nyaman, (4) kebutuhan akan perhatian, kasih sayang, (5) kebutuhan akan harga diri, (6) kebutuhan aktualisasi diri sehingga dapat mencapai hasil belajar yang maksimal, bermoral, dan bertanggungjawab. Selanjutnya mereka dapat diterima bekerja di dunia industri maupun dunia usaha, yang relevan dengan kompetensi yang dimilikinya. Karena kalau salah satu tidak terpenuhi ketika proses pembelajaran , motivasinya akan menurun atau sama sekali akan kehilangan motivasi belajarnya, sehingga jauh dari harapan DU/DI.

Rendahnya motivasi siswa dalam belajar, salah satu penyebabnya adalah penggunaan model pembelajaran yang konvensional, sehingga materi ajar tidak relevan dengan kebutuhan industri, produk yang dikerjakan tidak sesuai dengan keharusan pada kompetensi dunia kerja, yang hanya simulasi, semu dan tidak nyata, sehingga kalau keadaan ini terus menerus berjalan maka sistem pembelajaran tidak terpenuhi dan kompetensi kerja yang diharapkan oleh DUDI kurang relevan, akan semakin jauh dari harapan industri. 
Pencapaian kompetensi siswa harus diukur dengan cara yang bervariasi sesuai dengan kriteria kinerja yang harus dilakukan untuk memperoleh gambaran hasil belajar yang sebenarnya. Guna memperoleh hasil atau gambaran hasil evaluasi yang menggambarkan pencapaian kompetensi siswa maka harus dipergunakan teknik-teknik penilaian yang dapat menghasilkan data yang autentik, yaitu penilaian dilaksanakan secara langsung dalam proses pembelajaran dan berdasarkan hasil produk dari suatu standar kompetensi, sehingga akan memudahkan dalam pengisisan skill pasport sebagai bukti pencapaian kompetensi siswa, melalui sebuah kinerja . Pelaksanaan pencapaian kompetensi bisa berupa Uji Level, Ujian Tengah Semester, Ujian Akhir Semester serta Ujian Praktek Kejuruan atau disebut juga Uji Kompetensi, sekarang dikenal dengan nama UKK .(Uji Kompetensi Kejuruan )

Kompetensi merupakan perpaduan antara pengetahuan, keterampilan nilai dan sikap yang direfleksikan dalam kebiasaan berfikir dan bertindak. Sesuai dengan yang dikemukakan Mc. Ashan 1981 : 45 ( dalam Mulyasa, 2005 : 38/ bahwa kompetensi “... is a knowledge, skills, and abilities or capabilities that person achieves, which become part of his or her being to the event he or she can satisfactorilly perform particular cognitive, affective and psychomotorbehaviors".

Pengamatan peneliti terhadap situasi pembelajaran mata pelajaran produktif di SMK Negeri 9 Bandung ditemui hasil praktik yang menurun, penyelesaian tugas mata pelajaran produktif tidak tepat waktu, sehingga berdampak pada pencapaian kompetensi yang sesuai dengan kebutuhan pasar kerja, kemungkinan yang menjadi faktor penyebabnya antara lain :

1. Metode atau model pembelajaran produktif yang diterapkan belum sesuai dengan apa yang diharapkan oleh dunia usaha dan dunia industri

2. Isi pada materi pembelajaran produktif belum mengkondisikan siswa pada jabatan pekerjaan seperti di industri

3. Terjabi kesenjangan (gap) antara pembelajaran yang diterapkan disekolah dengan kebutuhan Du/Di sehingga kurang relevan antara kompetensi yang diajarkan di sekolah dengan kompetensi kerja yang dibutuhkan masyarakat. 
4. Turunnya motivasi belajar siswa sehingga berdampak pada nilai kompetensi yang dicapai. Perlu dikaji model pembelajaran yang menciptakan suasana akrab, saling menghargai, bekerja sama, menyenangkan atau meaning and joy full learning

5. Materi pembelajaran pada mata pelajaran produktif masih bersifat sempit sekedar memenuhi persyaratan nilai sebuah standar kompetensi

6. Model penilaian dalam pencapaian kompetensi pada mata pelajaran produktif masih menggunakan penilaian tertulis bersifat pencapaian kognitif saja sehingga belum menggambarkan kriteria kinerja yang utuh, menyeluruh dan sebenarnya

7. Belum optimalnya pemanfaatan dan penggunaan sarana /prasarana praktik pada mata pelajaran produktif di laboratorium Tata Busana dan Kompetensi keahlian Patiseri,

8. Belum seimbangnya ketercapaian kompetensi produktif dengan keterserapan pada pasar kerja, sehingga lulusan SMK semakin bertambah banyak dan berdampak pada pengangguran.

\section{METODE}

Metode penelitian yang digunakan untuk mengetahui kontribusi implementasi pembelajaran teaching industry berbasis kewirausahaan dan motivasi belajar terhadap peningkatan kompetensi keahlian produktif bidang Busana Butik dan Patiseri ini adalah penelitian deskriptif analisis menggunakan teknik penelitian korelasional. Penekanan pada penelitian korelasional memperkirakan hubungan antara dua atau lebih variabel. Jenis penelitian ini biasanya meliputi pengukuran statistik dari derajat hubungan.

Desain penelitian ini dipilih karena akan memperkirakan hubungan antara variabel persepsi tentang karir pekerjaan di industri dan motivasi belajar siswa terhadap pelaksanaan praktik kerja industri dengan pengukuran statistik, dimana hubungan variabel dinyatakan dengan koefisien korelasi dan keberartian (signifikasi). 
Teknik pengumpulan data yang dipergunakan dalam penelitian ini adalah dengan cara melakukan test, menyebarkan angket dan dokumentasi. Langkahlangkah pengolahan data dalam penelitian adalah :

a. Menyeleksi (editing) data yang telah dikumpulkan

b. Memberi skor terhadap item-item kuesioner berdasarkan pola skor kedalam tabel rekapitulasi data (tabulasi).

c. Menganalisis data kemudian diinterpretasikan untuk dapat menarik kesimpulan.

Analisis data dilakukan melalui tiga tahapan yaitu tahap deskripsi data, tahap uji persyaratan analisis dan tahapan pengujian hipotesis.

\section{HASIL PENELITIAN}

\section{A. Implementasi pembelajaran model teaching industry berbasis kewirausahaan}

Deskripsi mengenai implementasi pembelajaran model teaching industry berbasis kewirausahaan yang terdiri dari aspek sarana prasarana pembelajaran, proses pembelajaran, tenaga pendidik dan siswa yang tersaji dalam tabel dan grafik berikut ini.

Tabel 1. Deskripsi Data Hasil Penelitian Pada Aspek dan Indikator (Variabel $\mathrm{x}_{1}$ )

\begin{tabular}{ccccccccc}
\hline & N & Range & Min & Max & Sum & Mean & $\begin{array}{c}\text { Std. } \\
\text { Deviation }\end{array}$ & Prosentase \\
\hline X1.A & 67 & 12.00 & 23.00 & 35.00 & 1919.00 & 274,14 & 2,26 & $71,6 \%$ \\
X1.B & 67 & 40.00 & 100.00 & 140.00 & 6959.00 & 277,18 & 7,85 & $82,7 \%$ \\
X1.C & 67 & 04.00 & 06.00 & 10.00 & 575.00 & 287,50 & 0,91 & $85,8 \%$ \\
X1.D & 67 & 04.00 & 06.00 & 10.00 & 571.00 & 285,50 & 1,06 & $85,2 \%$ \\
Valid N & 67 & & & & & & & \\
(listwise) & & & & & & & & \\
\hline
\end{tabular}

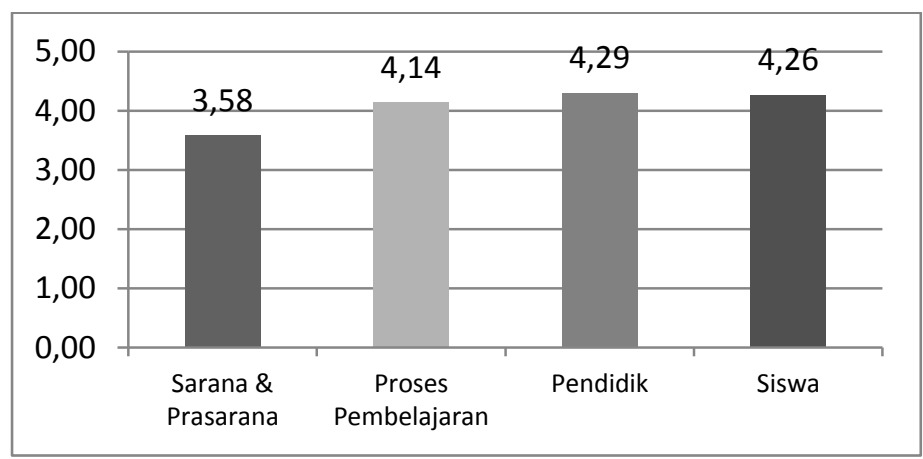

Gambar 1. Aspek dan Indikator pada Variabel Implementasi Pembelajaran Model Teaching Industry Berbasis Kewirausahaan 
Perhitungan data yang diperoleh dari 67 responden untuk variabel implementasi pembelajaran model teaching industry berbasis kewirausahaan diperoleh total skor 10807, berarti ada pada kategori tinggi, sehingga dapat di interpretasikan bahwa implementasi pembelajaran model teaching industry berbasis kewirausahaan telah dilaksanakan dengan baik.

Implementasi pembelajaran model teaching industry berbasis kewirausahaan tergambar pada pencapaian setiap indikator terhadap variabel ini. berdasarkan hasil pengolahan data terhadap skor responden diperoleh hasil perhitungan untuk ke tujuh indikator yang menunjukkan dukungan industri dalam pelaksanaan praktek kerja di tempat kerja.

1. Aspek sarana prasarana pembelajaran.

2. Aspek proses pembelajaran

3. Aspek tenaga pendidik .

4. Siswa.

\section{B. Motivasi Belajar dalam Implementasi Pembelajaran Model Teaching Industry Berbasis Kewirausahaan}

Deskripsi mengenai motivasi belajar siswa pada kompetensi keahlian produktif busana butik dan patiseri dalam implementasi pembelajaran model teaching industry berbasis kewirausahaan ditunjukan pada tabel dan grafik di bawah ini.

Tabel 2. Statistik Diskriptif Aspek dan Indikator Motivasi Belajar Siswa

\begin{tabular}{ccccccccc}
\hline & N & Range & Min & Max & Sum & Mean & $\begin{array}{c}\text { Std. } \\
\text { Deviation }\end{array}$ & Prosentase \\
\hline X2.A & 67 & 12.00 & 30.00 & 42.00 & 2495.00 & 277,12 & 2,69 & $82,8 \%$ \\
X2.B & 67 & 08.00 & 17.00 & 25.00 & 1434.00 & 286,80 & 2,04 & $85,6 \%$ \\
X2.C & 67 & 42.00 & 57.00 & 99.00 & 4281.00 & 285,40 & 5,99 & $85,2 \%$ \\
X2.D & 67 & 08.00 & 17.00 & 25.00 & 1426.00 & 285,30 & 1,87 & $85,1 \%$ \\
X2.E & 67 & 08.00 & 17.00 & 25.00 & 1390.00 & 278,00 & 1,83 & $83,0 \%$ \\
Valid N & 67 & & & & & & & \\
(listwise) & & & & & & & & \\
\hline
\end{tabular}




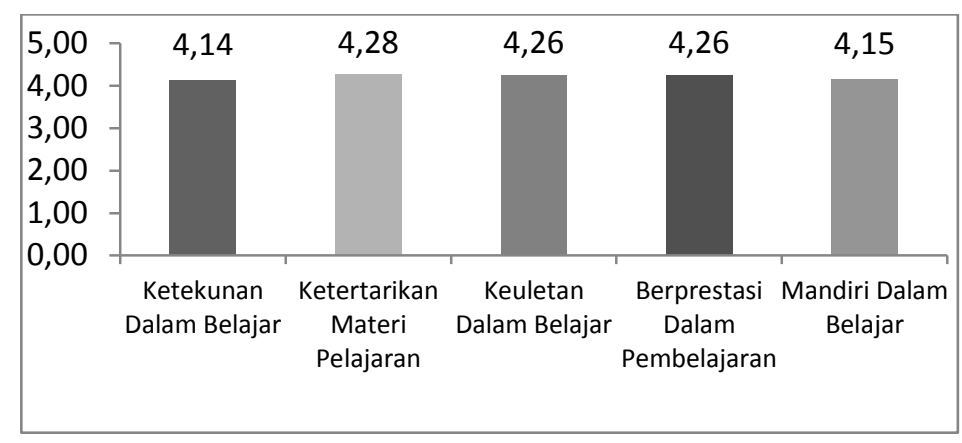

Gambar 2. Aspek dan Indikator Motivasi Belajar Siswa

Perhitungan data yang diperoleh dari 67 responden untuk variabel motivasi belajar pada implementasi pembelajaran model teaching industry berbasis kewirausahaan diperoleh total skor 10998, yang berarti ada pada kategori sangat tinggi. Hal ini dapat di interpretasikan bahwa siswa pada Kompetensi Keahlian Produktif Busana Butik dan Patiseri dalam implementasi pembelajaran model teaching industry berbasis kewirausahaan mempunyai motivasi belajar yang kuat untuk meningkatkan kompetensi yang relevan dengan kompetensi kerja yang dibutuhkan oleh DU/DI, dan pada akhirnya bias mandiri atau berwirausaha.

Variabel motivasi belajara siswa dalam implementasi pembelajaran model teaching industry berbasis kewirausahaan tergambar pada pencapaian setiap indikator yaitu:

- Ketekunan dalam belajar

- Ketertarian terhadap materi pembelajaran

- Keuletan dalam belajar dan ketajaman perhatian dalam belajar

- Berprestasi dalam pembelajaran

- Mandiri dalam belajar

\section{Peningkatan Kompetensi Keahlian Produktif Busana Butik dan Patiseri \\ Deskripsi data dari variabel peningkatan kompetensi keahlian produktif} Busana Butik dan Patiseri tergambar pada pencapaian setiap indikator pada variabel ini yaitu kompetensi kognitif, psikomotor, dan sikap kerja sesuai Tabel 3. 
Tabel 3. Statistik Deskriptif Aspek dan Indikator yang Menunjukkan Peningkatan Kompetensi Keahlian Produktif Busana Butik dan Patiseri

\begin{tabular}{ccccccccc}
\hline & N & Range & Min & Max & Sum & Mean & $\begin{array}{c}\text { Std. } \\
\text { Deviation }\end{array}$ & Prosentase \\
\hline Y..A & 67 & 02.00 & 04.00 & 06.00 & 383.00 & 63,83 & 0,65 & $95,3 \%$ \\
Y..B & 67 & 10.00 & 11.00 & 21.00 & 1276.00 & 63,80 & 2,01 & $95,2 \%$ \\
Y..C & 67 & 03.00 & 03.00 & 06.00 & 373.00 & 62,17 & 0,80 & $92,8 \%$ \\
Valid N & 67 & & & & & & & \\
(listwise) & & & & & & & & \\
\hline
\end{tabular}

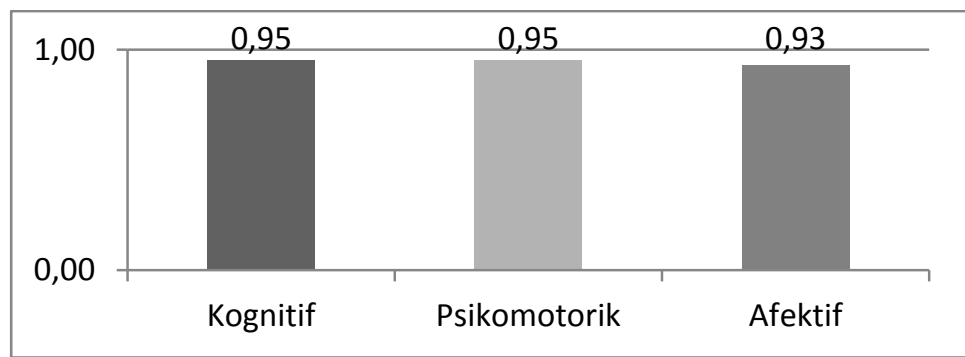

Gambar 3. Aspek dan Indikator Kompetensi Kognitif Keahlian Produktif Busana Butik dan Patiseri

Hasil perhitungan data yang diperoleh dari 67 responden untuk hasil variabel peningkatan kompetensi keahlian produktif Busana Butik dan Patiseri memperoleh skor 1866 . Angka ini berada pada kategori sangat tinggi. Hasil ini dapat di interpretasikan bahwa peningkatan kompetensi keahlian produktif Busana Butik dan Patiseri ada pada kategori sangat tinggi

Peningkatan kompetensi keahlian produktif busana butik dan patiseri ditunjukkan dengan 3 aspek berikut ini yaitu,

1. Kompetensi Kognitif

2. Keberhasilan dalam kompetensi psikomotor

3. Sikap

Hasil perhitungan korelasi pada tabel output SPSS 15.0 diinterpretasikan dengan dasar ketentuan sebagai berikut:

1. Koefisien korelasi implementasi pembelajaran model teaching industry berbasis kewirausahaan terhadap peningkatan kompetensi keahlian produktif positif 0,653 berarti keeratan korelasi kedua variabel tersebut kuat. Nilai p-value pada kolom sig. (1-tailed) $0,000<0,05$ level of significant (́́) Berarti Ha3 ditolak dan Ho3 diteima yang artinya 
implementasi pembelajaran model teaching industry berbasis kewirausahaan berkorelasi kuat dengan peningkatan kompetensi keahlian produktif.

2. Koefisien korelasi motivasi belajar dengan peningkatan kompetensi keahlian produktif positif 0,663 berarti keeratan korelasi kedua variabel tersebut kuat. Nilai p-value pada kolom sig. (1-tailed) $0,000<0,05$ level of significant (ó) Berarti Hal diterima dan Hol ditolak yang artinya motivasi belajar berkorelasi kuat terhadap peningkatan kompetensi keahlian produktif

3. Koefisien korelasi antara Implementasi pembelajaran model teaching industry berbasis kewirausahaan terhadap motivasi belajar 0,418 berarti keeratan korelasi kedua variabel tersebut kuat.

Perhitungan analisis regresi linier sederhana dipergunakan untuk mengungkapkan hubungan fungsional antara variabel $\mathrm{X}_{1}$ dan $\mathrm{Y}$, berdasarkan hasil perhitungan dengan menggunakan koefisien B pada tabel coeffisients dapat dihasilkan sebagai berikut:

Tabel 4. Hasil Perhitungan Uji Regresi Sederhana Variabel $\mathrm{X}_{1}$ Dengan $\mathrm{Y}$

\begin{tabular}{|c|c|c|c|c|c|}
\hline \multicolumn{6}{|c|}{ Coefficients $^{a}$} \\
\hline \multirow[b]{2}{*}{ Model } & \multicolumn{2}{|c|}{ Unstandardized Coefficients } & \multirow{2}{*}{$\begin{array}{c}\text { Standardized } \\
\text { Coefficients } \\
\text { Beta }\end{array}$} & \multirow[b]{2}{*}{$\mathbf{t}$} & \multirow[b]{2}{*}{ Sig. } \\
\hline & B & Std. Error & & & \\
\hline 1 (Constant) & 17,358 & 4,804 & & 3,613 & ,001 \\
\hline $\mathrm{X} 1$ & ,656 & ,094 & ,653 & 6,951 &, 000 \\
\hline
\end{tabular}

Pada tabel di atas menunjukkan bahwa persamaan regresi sederhana sebagai berikut : $\hat{Y}=17,358+0,656 \mathrm{X}_{1}$

Berdasarkan kaidah pengujian signifikansi ternyata $F_{\text {hitung }}$ lebih besar dari $\mathrm{F}_{\text {tabel }}$, atau 6,95 > 3,61 maka Ho diterima , artinya terdapat kontribusi yang signifikan antara implementasi pembelajaran model teaching industry berbasis kewirausahaan terhadap peningkatan kompetensi keahlian produktif Busana Butik dan Patiseri.

Perhitungan analisis regresi linier sederhana dipergunakan untuk mengungkapkan hubungan fungsional antara variabel $\mathrm{X}_{2}$ dan $\mathrm{Y}$, berdasarkan hasil dengan menggunakan koefisien B pada tabel coeffisients dapat dihasilkan sebagai berikut: 
Tabel 5. Hasil Perhitungan Uji RegresiSederhana Variabel $\mathrm{X}_{2}$ dengan $\mathrm{Y}$

\section{Coefficients $^{\mathrm{a}}$}

\begin{tabular}{|c|c|c|c|c|c|}
\hline \multirow[b]{2}{*}{ Model } & \multicolumn{2}{|c|}{ Unstandardized Coefficients } & $\begin{array}{c}\text { Standardized } \\
\text { Coefficients } \\
\end{array}$ & \multirow[b]{2}{*}{$\mathrm{t}$} & \multirow[b]{2}{*}{ Sig. } \\
\hline & $\mathrm{B}$ & Std. Error & Beta & & \\
\hline $1 \quad$ (Constant) & 16,828 & 4,752 & & 3,541 & 001 \\
\hline$x 2$ & 629 & 088 & .663 & 7,140 & .000 \\
\hline
\end{tabular}

a. Dependent Variable: $Y$

Pada tabel di atas menunjukkan bahwa persamaan regresi sederhana sebagai berikut;

$$
\hat{\mathrm{Y}}=16,828+0,629 \mathrm{X}_{2}
$$

Berdasarkan kaidah pengujian signifikansi ternyata $F_{\text {hitung }}$ lebih besar dari $\mathrm{F}_{\text {tabel }}$, atau 7,14>3,54 maka Ho diterima , artinya terdapat kontribusi yang signifikan antara motivasi belajar siswa terhadap peningkatan kompetensi keahlian produktif Busana Butik dan Patiseri.

Perhitungan analisis regresi linier sederhana dipergunakan untuk mengungkapkan hubungan fungsional antara variabel $\mathrm{X}_{1}$ dan $\mathrm{X}_{1}$ dengan $\mathrm{Y}$, berdasarkan hasil perhitungan dengan menggunakan koefisien $\mathrm{B}$ pada tabel coeffisients dapat dihasilkan sebagai berikut:

Tabel 6. Hasil Perhitungan Uji Regresi Ganda Variabel $\mathrm{X}_{1}, \mathrm{X}_{2}$ dengan Variabel Y

\begin{tabular}{|c|c|c|c|c|c|c|}
\hline & & \multicolumn{5}{|c|}{ Coefficientsa } \\
\hline \multirow{2}{*}{\multicolumn{2}{|c|}{ Model }} & \multicolumn{2}{|c|}{$\begin{array}{c}\text { Unstandardized } \\
\text { Coefficients }\end{array}$} & \multirow{2}{*}{$\begin{array}{c}\text { Standardized } \\
\text { Coefficients } \\
\text { Beta }\end{array}$} & \multirow[b]{2}{*}{$\mathrm{t}$} & \multirow[b]{2}{*}{ Sig. } \\
\hline & & $\mathrm{B}$ & Std. Error & & & \\
\hline \multirow[t]{3}{*}{1} & (Constant) & 3,555 & 4,712 & & ,754 & ,453 \\
\hline & $\mathrm{X} 1$ & ,457 & ,086 & ,455 & 5,302 & ,000 \\
\hline & $\mathrm{x} 2$ & ,448 & ,081 & ,473 & 5,502 &, 000 \\
\hline
\end{tabular}

a. Dependent Variable: $Y$

Pada tabel di atas menunjukkan bahwa persamaan regresi ganda sebagai berikut ;

$$
\hat{Y}=3,555+\mathbf{0},, 457 X_{1}+, 448 X_{2}
$$

Berdasarkan kaidah pengujian signifikansi ternyata $F_{\text {hitung }}$ lebih besar dari $\mathrm{F}_{\text {tabel }}$, atau 5,50>5,30 maka Ho diterima , artinya terdapat kontribusi yang signifikan antara implementasi pembelajaran model teaching industry berbasis 
kewirausahaan dan motivasi belajar siswa terhadap peningkatan kompetensi keahlian produktif Busana Butik dan Patiseri.

\section{PEMBAHASAN}

Kontribusi Implementasi Pembelajaran Model Teaching Industry berbasis Kewirausahaan terhadap peningkatan kompetensi keahlian produktif mempunyai kriteria tinggi. Hasil penelitian ini menunjukkan bahwa implementasi pembelajaran model Teaching Industry Berbasis Kewirausahaan telah dilaksanakan dengan baik. Implementasi Pembelajaran Model Teaching Industry berbasis Kewirausahaan tergambar pada pencapaian setiap aspek dan indikator diantaranya sarana prasarana pembelajaran, proses pembelajaran, tenaga pendidik dan siswa pada implementasi pembelajaran model teaching industry berbasis kewirausahaan sangat mendukung, baik dilihat dari kondisi, kelengkapan, kesesuaian kurikulum, kesiapan tenaga pendidik dan siswa dapat terpenuhi secara baik.

Kontribusi motivasi belajar siswa terhadap Peningkatan Kompetensi Keahlian Produktif Busana Butik dan Patiseri mempunyai kriteria tinggi Motivasi belajar yang tinggi dalam peningkatan kompetensi yang relevan dengan kompetensi kerja yang dibutuhkan oleh DUDI, sehingga bisa mandiri di dalam berwirausaha. Motivasi belajar siswa dalam implementasi pembelajaran model teaching industry berbasis kewirausahaan tergambar pada pencapaian setiap indikator ketekunan dalam belajar, ketertarian terhadap materi pembelajaran, keuletan dalam belajar dan ketajaman perhatian dalam belajar, berprestasi dalam pembelajaran, mandiri dalam belajar.

Kontribusi implementasi pembelajaran model teaching industry berbasis kewirausahaan dan motivasi belajar siswa secara bersama-sama terhadap peningkatan kompetensi keahlian produktif Busana Butik dan Patiseri berada pada kriteria tinggi . Upaya peningkatan kompetensi Keahlian Produktif Busana Butik dan Patiseri sangat ditentukan oleh besaran keterlibatan siswa dalam aktivitas belajar selama pembelajaran. Pembelajaran dengan model teaching industry berbasis kewirausahaan ini merupakan suatu wadah untuk mencapai 
peningkatan kompetensi kognitif, psikomotor dan sikap kerja sesuai standar kompetensi kerja yang diharapkan industri yang relevan .

Implementasi pembelajaran model teaching industry berbasis kewirausahaan mempunyai kontribusi yang besar terhadap peningkatan kompetensi keahlian produktif Busana Butik dan Patiseri baik dalam kompetensi kognitif, psikomotor dan sikap kerja yang relevan dengan kompetensi kerja yang diharapkan oleh dunia industri atau lembaga, serta instansi yang relevan. tetapi masih perlu ditingkatkan secara berkelanjutan, karena motivasi sifatnya kondisional dan selalu berubah. Pembelajaran model teaching industry berbasis kewirausahaan dapat memberikan pengayaan, suatu langkah inovatif untuk pengembangan pendidikan teknologi dan kejuruan khususnya pendidikan jalur professional dalam peningkatan kompetensi siswa yang bermuara pada kualitas sumber daya manusia, yang dapat memiliki kompetensi kerja yang diharapkan oleh DUDI.

Motivasi belajar siswa pada Kompetensi Keahlian Produktif Busana Butik dan Patiseri dalam implementasi pembelajaran model teaching industry berbasis kewirausahaan mempunyai kontribusi yang besar terhadap peningkatan kompetensi keahlian produktif Busana Butik dan Patiseri. Terdapat dalam kompetensi kognitif, psikomotor dan sikap kerja yang relevan dengan kompetensi kerja yang diharapkan oleh dunia industri atau lembaga, serta instansi yang relevan. tetapi masih perlu ditingkatkan secara berkelanjutan, karena motivasi sifatnya kondisional dan selalu berubah.

Motivasi belajar siswa tergambar pada pencapaian setiap indikator yaitu: ketekunan dalam belajar, ketertarikan terhadap materi pembelajaran, keuletan dalam belajar dan ketajaman perhatian dalam belajar, berprestasi dalam pembelajaran, mandiri dalam belajar sehingga dapat meningkatkan motivasi belajar serta kompetensi yang relevan dengan kompetensi kerja yang dibutuhkan oleh industri,. pada akhirnya bisa mandiri atau berwirausaha.

Motivasi belajar dalam konsep pembelajaran model teaching industry ber basis kewirausahaan sangat tergantung pada upaya mengatur kedua peran baik learning maupun working di tempat kerja. Motivasi belajar atau motivasi untuk berprestasi dalam melakukan sesuatu (learning to do) atau belajar sambil bekerja 
(learning by doing) dalam model pembelajaran melalui pembelajaran model teaching industry berbasis kewirausahaan merupakan dorongan atau semangat yang menggerakkan siswa untuk melakukan berbagai aktivitas pembelajaran secara nyata.

Implementasi pembelajaran model teaching industry berbasis kewirausahaan dan motivasi belajar siswa merupakan suatu model pembelajaran yang inovatif, relevan dan mendukung kebutuhan kompetensi kerja yang diharapkan oleh industri sehingga dapat memberikan kontribusi yang besar terhadap peningkatan kompetensi keahlian produktif, yang diharapkan dunia kerja. Implementasi pembelajaran model teaching industry berbasis kewirausahaan dan motivasi belajar siswa dapat saling menunjang satu sama lain sehingga keduanya harus berjalan secara kontinou dan seimbang supaya dapat mencapai peningkatan kompetensi yang diharapkan.

Hasil kontribusi implementasi pembelajaran model teaching industry berbasis kewirausahaan dan motivasi belajar mempunyai kontribusi yang besar terhadap peningkatan kompetensi keahlian produktif Busana Butik dan Patiseri , Diharapkan kepada pemegang kebijakan hasil penelitian ini dapat dijadikan sebagai masukan bahwa perlunya ditingkatkan model atau pendekatan pembelajaran yang bersifat inovatif serta membangkitkan motivasi siswa sehingga dapat meningkatkan kompetensi baik softskill dan hardskill yang diharapkan oleh dunia industri dan masyarakat.

Untuk Sekolah khususnya Sekolah Menengah kejuruan atau SMK perlu memperhatikan strategi pembelajaran model teaching industry berbasis kewirausahaan supaya dapat memenuhi kebutuhan tenaga kerja yang terlatih secara komprehensif. Pengalaman positif yang mengukuhkan kegiatan pembelajaran bermakna dan dilakukan secara nyata yang berkelanjutan harus terpelihara dengan melakukan evaluasi pelaksanaan program secara periodik, dilanjutkan dengan tindak lanjut hasil evaluasi program meningkatkan motivasi belajar siswa sehingga akan menumbuhkan motivasi yang kuat dalam melakukan setiap aktivitas yang positif pada pembelajaran .

Untuk pengembang kurikulum dan manajemen sekolah perlu memperhatikan pengaruh, proses pelaksanaan pembelajaran yang inovatif dalam 
peningkatan kompetensi serta hasil belajar sehingga masyarakat dapat merasakan bahwa upayanya membawa hasil yang baik untuk peserta didik. Selain itu tenaga kependidikan diharapkan secara kontinou dapat meningkatkan perannya untuk membangkitkan motivasi belajar siswa dalam melakukan sesuatu (learning to do) atau belajar sambil bekerja (learning by doing) dalam model pembelajaran ini dengan mengarahkan siswa pada pembelajaran yang nyata dan bermakna bagi kehidupannya sesuai manajemen industri yang merupakan dorongan atau semangat yang menggerakkan siswa pada setiap kompetensi keahlian produktif untuk melakukan berbagai aktivitas latihan belajar sambil bekerja.

\section{KESIMPULAN}

Kontribusi implementasi pembelajaran model teaching industry berbasis kewirausahaan terhadap peningkatan kompetensi keahlian produktif mempunyai kriteria yang tinggi. Hasil penelitian ini menunjukkan bahwa implementasi pembelajaran model teaching industry berbasis kewirausahaan telah dilaksanakan dengan baik. Implementasi pembelajaran model teaching industry berbasis kewirausahaan tergambar pada pencapaian setiap indikator diantaranya sarana prasarana pembelajaran, proses pembelajaran, tenaga pendidik dan siswa pada implementasi pembelajaran model teaching industry berbasis kewirausahaan sangat mendukung, baik dilihat dari kondisi, kelengkapan, kesesuaian kurikulum, kesiapan tenaga pendidik dan siswa dapat terpenuhi terpenuhi secara baik.

Kontribusi motivasi belajar siswa terhadap peningkatan kompetensi keahlian produktif busana butik dan patiseri mempunyai kriteria yang tinggi motivasi belajar yang tinggi untuk meningkatkan kompetensi yang relevan dengan kompetensi kerja yang dibutuhkan oleh DU/DI, dan pada akhirnya bisa mandiri atau berwirausaha. Motivasi belajar siswa dalam implementasi pembelajaran model teaching industry berbasis kewirausahaan tergambar pada pencapaian setiap indikator ketekunan dalam belajar, ketertarian terhadap materi pembelajaran, keuletan dalam belajar dan ketajaman perhatian dalam belajar, berprestasi dalam pembelajaran, mandiri dalam belajar.

Ketiga variabel bersama-sama implementasi pembelajaran model teaching industry berbasis kewirausahaan dan motivasi belajar siswa secara bersama-sama 
terhadap peningkatan kompetensi keahlian produktif Busana Butik dan Patiseri menunjukkan kontribusi yang tinggi. Usaha meningkatkan kompetensi siswa pada Kompetensi Keahlian Produktif Busana Butik dan Patiseri sangat ditentukan oleh besaran keterlibatan siswa dalam aktivitas belajar selama pembelajaran .Pembelajaran dengan model teaching industry berbasis kewirausahaan ini merupakan suatu wadah untuk mencapai peningkatan kompetensi kognitif, psikomotor dan sikap kerja sesuai standar kompetensi kerja yang diharapkan industri yang relevan .

\section{DAFTAR PUSTAKA}

Asian Brain.com Content Team, Motivasi Belajar, http://www.anneahira.com/ motivasi/ index.htm. 16/10/2009 7.55

Bachtiar Hasan, (2008), Manajemen Industri Edisi 4, Pustaka Ramadhan, Bandung.

Bachtiar Hasan, (2010), Cara Praktis Membangun Wirausaha, Pustaka Ramadhan, Bandung

Calfrey C. Calhoun and Alton V Finch, (1976), Vocational Education: Concepts and Operations, Secon Edition, Wads Worth Publishing Company, Belmont, California

David Boud and Nicky Solomon, (2003), Work-based Learnig A New Higher Education, SRHE and Open Unuversity Press Celtic Court 22 Ballmoor Buckingham.

Departemen Pendidikan Nasional, (2007), Manajemen Unit Produksi, Direktorat PSMK , Tenaga Kependidikan, Jakarta.

E.Mulyasa. (2008),Kurikulum Berbasis Kompetensi, PT Remaja RosdaKarya, Bandung.

Elfindri, dkk, (2010), Soft Skill untuk Pendidik, Praninta Offset,Baduose Media

Jon Lauglo and Ruert Maclean. (2005), Vocationalosation of Secondary Education Revisited, Springer, Netherland

Melvin D. Miller, (1985), Principles and Philosofphy for Vocational Education, The National Center of Research in Vocational Education, The Ohio University, Columbus, Ohio.

Riduan, (2003), Dasar-dasar Statistika Edisi Revisi, Alfabeta, Bandung.

Sardiman, (2009), Interaksi dan Motivasi Belajar Mengajar, PT. Raja Garvindo Persada, Jakarta

Sudjana (2005), Metoda Statika, Tarsito, Bandung. 